Case Report

\title{
A Case of Newcastle Disease Virus in Red-Headed Lovebird in Sudan
}

\author{
Egbal Sidahmed Abdelrahim and Jedda Elhag \\ Veterinary Research Institute, P.O. Box 8067, Khartoum, Sudan \\ Correspondence should be addressed to Egbal Sidahmed Abdelrahim; igbalsss@hotmail.com
}

Received 16 July 2014; Accepted 6 October 2014; Published 30 October 2014

Academic Editor: Nektarios D. Giadinis

Copyright (C) 2014 E. Sidahmed Abdelrahim and J. Elhag. This is an open access article distributed under the Creative Commons Attribution License, which permits unrestricted use, distribution, and reproduction in any medium, provided the original work is properly cited.

\begin{abstract}
Two diseased red-headed lovebirds were presented for diagnosis to the Department of Avian Diseases and Diagnosis, Veterinary Research Institute, aged 37 days and 4 years. The symptoms were dyspnea, cyanosis of the comb, diarrhea, and fever. Postmortem lesions included pale liver and bloody enteritis. Newcastle disease virus was isolated from lungs, trachea, and intestines following inoculation in the allantoic cavity of 10-day-old fertile eggs; the NDV was identified by the means of HA\&HI tests using specific NDV antisera (Lasota strain). The isolate agglutinated equine RBCs but failed to agglutinate sheep and bovine RBCs. The pathogenicity of the NDV isolate was studied, the mean death time was 96 hours, and the intracerebral pathogenicity index (ICPI) value was 0.9 , indicating the isolate of lentogenic type.
\end{abstract}

\section{Introduction}

The red-headed lovebird (Agapornis pullarius) also known as the red-faced lovebird is a mostly green parrot and is a member of the family Psittaculidae, subfamily Agapornithinae, genus Agapornis, a group commonly known as lovebirds. Likeother lovebirds it is native to a wide range of Africa [1].

Newcastle disease (ND) is a highly contagious viral disease affecting over 250 species of birds of all age groups [2] and it is caused by newcastle disease virus (NDV) a linear, nonsegmented single stranded, enveloped, negative sense RNA virus belonging to the genus Rubulavirus of subfamily Paramyxovirinae and family Paramyxoviridae [3]. In Sudan, the ND was first reported in chickens in 1951 [4]. In other species, Khalafalla et al. (1990) [5] studied the role of some Passeriformes birds in experimental transmission of ND under Sudan conditions. In pigeons it was reported by Eisa and Omer (1984) [6]. A high level of susceptibility to NDV has been reported in Psitttaciformes [7]. Senthuran et al. (2005) [8] isolated four NDV obtained from a pigeon, lory, parrot, and lovebird.

\section{Case Presentation}

A diseased case of red-headed lovebird coming from Halfaya district in Khartoum state was submitted for diagnosis to the Department of Avian Diseases and Diagnosis, Veterinary Research Institute, Khartoum, Sudan. The age of birds was 37 days old and a parent bird was 4 years old; these lovebirds were reared close to chicken farms. The symptoms consisted of dyspnea, cyanosis of the comb, diarrhea, and fever. The birds were slaughtered; postmortem lesions were recorded including pale liver and bloody enteritis. Bacteriological examination of liver was done by streaking the samples on specific media (nutrient, MacConkey, blood agar, and xylose lysine deoxycholate (XLD) media) to study the presence of pathogenic bacterial agents but no significant bacterial agents were isolated. The trachea, lungs, and intestines were processed for virus isolation.

2.1. Virus Isolation. Virological examination was carried out according to guidelines of the OIE (2012). In brief the processed tissues were inoculated on five 10-day-old embryonated chickens via allantoic cavity, then incubated at $37^{\circ} \mathrm{C}$ 
for 7 days, and candled daily; the 24-hour death of embryos were discarded. The NDV isolate killed the embryos 5-7 days after inoculation. The allantoic fluid then was collected from the dead embryos and tested for haemagglutination of $1 \%$ chicken RBCS. The isolate was identified by haemagglutination inhibition (HI) test using NDV antiserum (Lasota strain).

2.2. Biological Properties of the NDV. The isolated virus was tested for ability to agglutinate sheep, bovine, and equine erythrocytes. It was found that the virus isolated had ability to agglutinate $1 \%$ equine RBCs but did not agglutinate sheep and bovine ones.

2.3. Biological Pathogenicity Assessment. The pathogenic evaluation of the isolate was carried out using standard assay methods to determine the intracerebral pathogenicity index (ICPI) in 1-day-old chicks [3]. This was done by inoculation of 1-day-old chicks intracerebrally with $0.1 \mathrm{~mL}$ of a $1: 10$ dilution of fresh infective allantoic fluid ( of $10^{7} \log _{2}$ HA titre). Chicks were monitored during an 8-day observation period and scored as normal (0), sick or paralyzed (1), and dead (2). Total scores were determined, and the mean daily score was calculated to obtain the ICPI as previously described [9]. The ICPI value was found to be 0.9 . The mean death time (MDT) determinations were performed as previously reported [10] and calculated for this isolate and found to be 96 hours.

\section{Discussion}

Newcastle disease has been classified as a notifiable diseases list of terrestrial animals (April 2013). In this study NDV was recovered from a natural infection affecting psittacine bird. This bird may play a role in the transmission of NDV to domestic chickens as no routine vaccination programme was adopted by the owners to the birds. This hypothesis was supported by findings of Cattoli et al. (2011) [11] who implied that the psittacine birds have been implicated in the maintenance of NDV infections and in transmission of the disease to poultry species. The role of lovebird in the epidemiological plan as the potential source of NDV infection has been documented [12]; they showed that lovebirds can be carriers of NDV and highlighted on the importance of lovebirds from the epidemiological point of view as potential source of infection of the NDV to other avian species that could be raised near this species.

The distribution of avian paramyxoviruses appears to be worldwide as they have been isolated from wild, captive, caged, and domestic birds [13].

NDV could be grouped into "velogenic" which is highly virulent, "mesogenic" which is of moderate virulence, and "lentogenic" which is of low virulence [14]. In this study the virus isolated was typed as lentogenic strain. In this report NDV was isolated from the lovebird and has a lentogenic characteristics based on the ICPI and MDT. The lentogenic strains were most probably the circulating strains used in live vaccines.

For our knowledge this is the first report of isolation of NDV lovebird in Sudan. Other studies are needed to know the role of this species in transmission of the virus to domestic chickens and also antigenic and molecular studies are highly recommended.

\section{Conflict of Interests}

The authors declare that there is not conflict of interests regarding the publication of this paper.

\section{References}

[1] Bird Life International, "Agapornis pullarius," in IUCN Red List of Threatened Species. Version 2013, 2012.

[2] D. J. Alexander, "Newcastle disease and other avian Paramyxoviridae infections," in Diseases of Poultry, B. W. Calnek, H. J. Barnes, C. W. Beard, L. R. McDougald, and Y. M. Saif, Eds., vol. 26, pp. 541-570, Iowa State University Press, Ames, Iowa, USA, 10th edition, 1997.

[3] OIE, "Manual of Diagnostic Tests and Vaccines for Terrestial Animal," Newcastle disease, Chapter 2.3.14. pp 1-19, 2012.

[4] Anon, "Annual report of the Sudan Veterinary services," 1951.

[5] A. I. Khalafalla, A. A. Nayil, A. H. Nimir, and I. Hajer, "Role of some passeriformes birds in transmission of Newcastle disease: I-Susceptibility of some wild birds of Sudan to Newcastle disease virus," Bulletin of Animal Health and Production in Africa, vol. 38, no. 1, pp. 45-49, 1990.

[6] M. Eisa and E. A. Omer, "A natural outbreak of Newcastle disease in pigeons in the Sudan," Veterinary Record, vol. 114, no. 12, article 297, 1984.

[7] G. A. Erickson, C. J. Maré, G. A. Gustafson, L. D. Miller, S. J. Proctor, and E. A. Carbrey, "Interactions between viscerotropic velogenic Newcastle diseases virus and pet birds of six species. I. Clinical and serologic responses, and viral excretion.," Avian Diseases, vol. 21, no. 4, pp. 642-654, 1977.

[8] S. Senthuran, K. Vijayarani, K. Kumanan, and A. M. Nainar, "Pathotyping of Newcastle disease virus isolates from pet birds," Acta Virologica, vol. 49, no. 3, pp. 177-182, 2005.

[9] C. Terregino and I. Capua, "Conventional diagnosis of Newcastle disease virus infections," in Avian Influenza and Newcastle Disease: A Field and Laboratory Manual, I. Capua and D. J. Alexander, Eds., pp. 123-125, Springer, Milan, Italy, 2009.

[10] R. P. Hanson and C. A. Brandy, "Identification of vaccine strains of Newcastle disease virus," Science, vol. 122, no. 3160, pp. 156157, 1955.

[11] G. Cattoli, L. Susta, C. Terregino, and C. Brown, "Newcastle disease: a review of field recognition and current methods of laboratory detection," Journal of Veterinary Diagnostic Investigation, vol. 23, no. 4, pp. 637-656, 2011.

[12] G. R. V. Martins, A. C. Paulillo, E. M. D. S. Schmidt, J. Denadai, A. T. Carrasco, and I. F. C. dos Santos, "Relevance of lovebirds (Agapornis roseicollis Selby, 1836) in experimental epidemiology of Newcastle disease," International Journal of Poultry Science, vol. 11, no. 5, pp. 338-340, 2012.

[13] Y. Shengqing, K. Shinya, K. Otsuki, H. Ito, and T. Ito, "Isolation of myxoviruses from migratory waterfowls in San-in district, western Japan in winters of 1997-2000," Journal of Veterinary Medical Science, vol. 64, no. 11, pp. 1049-1052, 2002.

[14] D. J. Alexander and D. A. Senne, "Newcastle disease," in Disease of Poultry, A. M. Saif, A. M. Fadly, J. R. Glisson, L. R. McDougald, L. K. Nolan, and D. E. Sywane, Eds., pp. 75-100, Blackwell, London, UK, 10th edition, 2008. 

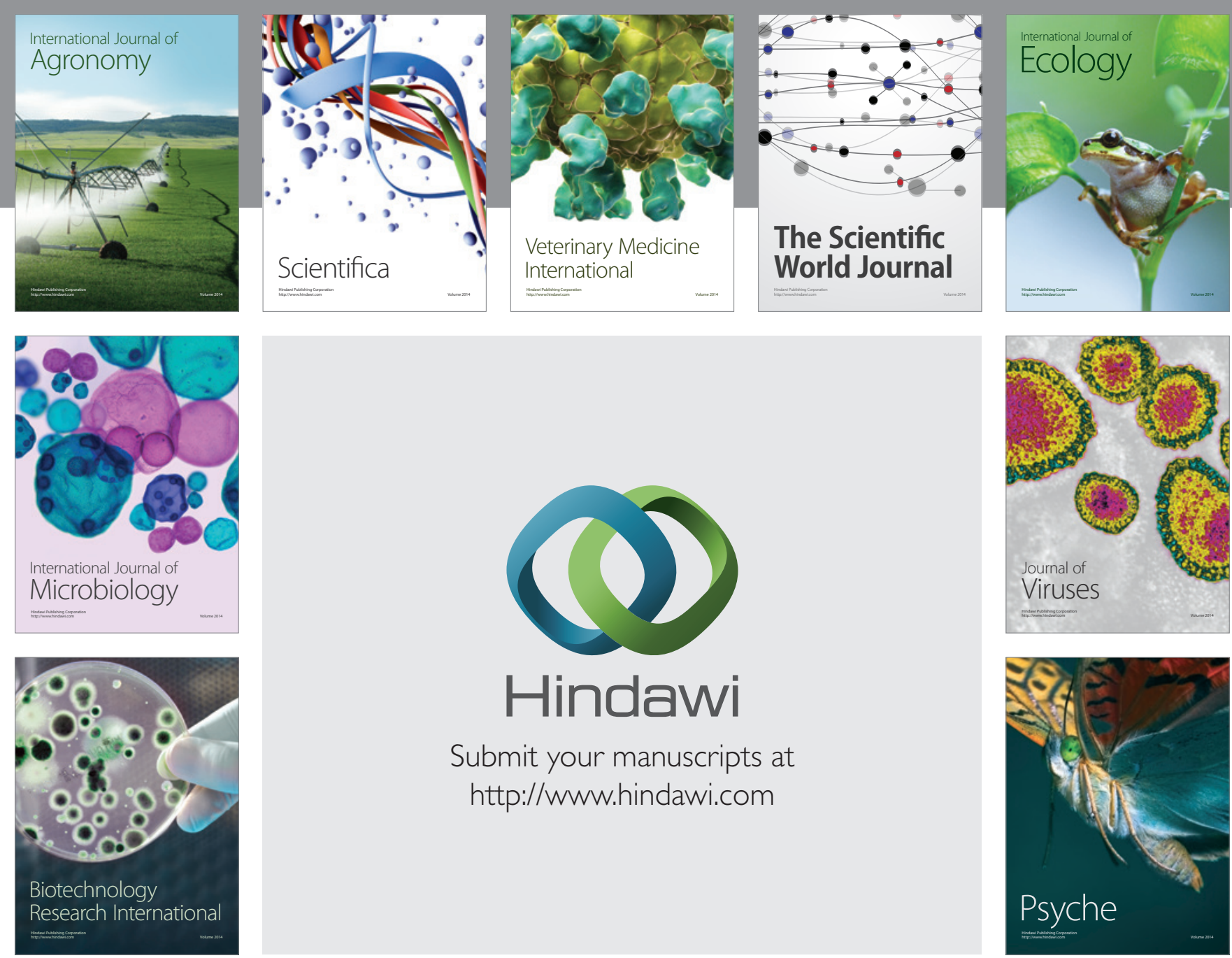

Submit your manuscripts at http://www.hindawi.com
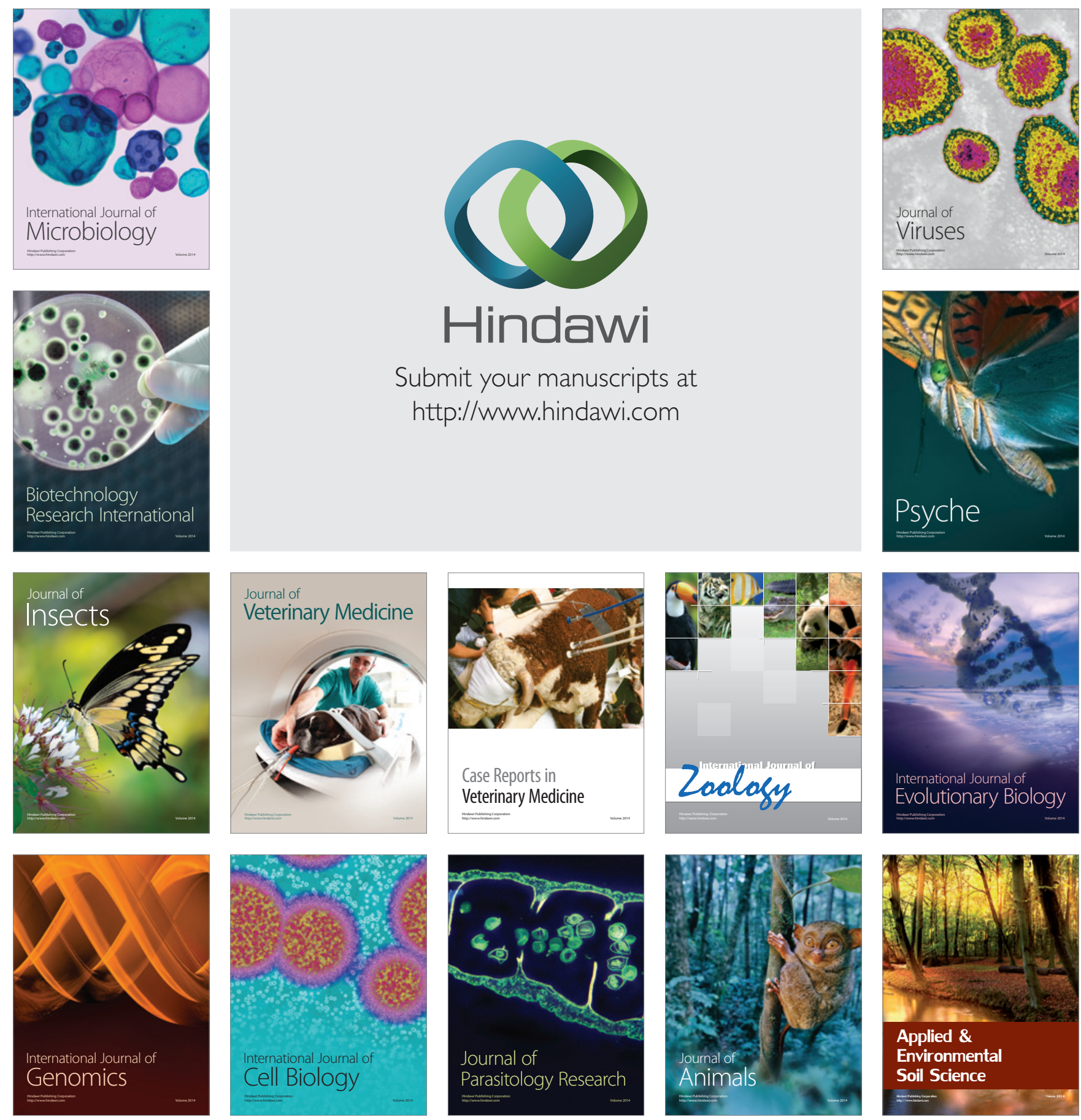